\title{
PENGARUH PELATIHAN TERHADAP KEPATUHAN PERAWAT DALAM PELAKSANAAN PERAWATANWATER SEAL DRAINAGE SESUAI STANDAR PROSEDUR OPERASIONAL
}

\author{
Murjani $^{1}$, Hamzah $^{2}$, Muhsinin $^{3}$ \\ ${ }^{1}$ Mahasiswa Pascasarjana Ilmu Keperawatan Universitas Muhammadiyah Banjarmasin, 70114, \\ Indonesia \\ ${ }^{2}$ Staff Dosen Universitas Airlangga Surabaya, 60132,Indonesia \\ ${ }^{3}$ Staff Dosen Pascasarjana Ilmu Keperawatan Universitas Muhammadyah Banjarmasi, 70114, Indonesia \\ Email : uzanxesta@gmail.com
}

\begin{abstract}
ABSTRAK
Latar Belakang: Perawat yang bertanggung jawab dalam perawatan pasien post pemasangan WSD harus memiliki pengetahuan yang baik dalam mengelola sistem drainase dengan benar. Pendidikan dan pelatihan yang tepat diperlukan untuk meningkatkan kepatuhan staf perawat dalam pelaksanan perawatan WSD sesuai SPO. Penelitian ini bertujuan untuk mengetahui pengaruh pelatihan terhadap kepatuhan pelaksanaan perawatan water seal drainage (WSD) sesuai standar prosedur operasional di RSUD Ulin Banjarmasin.

Metode: Penelitian ini menggunakan desain quasi experiment dengan pendekatan one group pre-post test without control group design, sampel yang digunakan adalah perawat Ruang Rawat Inap RSUD Ulin sebanyak 20 orang yang dipilih dengan teknik porposive sampling.

Hasil: Kepatuhan perawat sebelum mendapatkan pelatihan perawatan WSD mean 32,00. Kepatuhan perawat sesudah mendapatkan pelatihan perawatan WSD mean 39,40. Perubahan kepatuhan perawat sebelum dan sesudah mendapatkan pelatihan perawatan WSD dengan Mean Paired Differences yaitu sebesar -7,400 dengan signifikansi 0,000 dapat disimpulkan bahwa terdapat pengaruh pelatihan terhadap kepatuhan pelaksanaan perawatan WSD.

Kesimpulan: Pihak manajemen SDM dan bidang DIKLIT agar dapat meningkatkan kemampuan perawat dengan cara menyelenggarakan pendidikan dan pelatihan secara adil dan merata kepada perawat klinik II.
\end{abstract}

Kata Kunci: Pelatihan, Kepatuhan Perawat, Perawatan Water Seal Drainage 


\section{PENDAHULUAN}

Pemasangan drainage dada merupakan terapi standar pada berbagai penyakit pleura seperti pneumotoraks, efusi pleura malignansi, luka tembus dada, hemotoraks, empiema, chylothorax dan fistula bronkopleura. (Rosadi dkk, 2014). Berbagai masalah dan komplikasi dapat timbul selama perawatan. Penelitian Mohammed et al (2016) menjelaskan bahwa perawatan WSD dan manajemen sistem drainase yang tidak tepat dapat menyebabkan evakuasi cairan atau udara tidak lengkap mengakibatkan penundaan reekspansi paru. Sahib et al (2019) juga menjelaskan bahwa jika drainage tersumbat, hemothorax yang tertahan, empiema dan peningkatan risiko infeksi adalah masalah yang sering muncul. Hal ini juga ditegaskan pada penelitian Ayoub et al (2019), dimana komplikasi infeksi dapat berkembang pada $2 \%$ hingga $25 \%$ pada pasien yang dengan pemasangan WSD. Pasien yang dirawat selama lebih dari 20 hari hampir 6 kali lebih mungkin untuk terjadi infeksi daripada pasien dengan pemasangan WSD kurang dari 20 hari. (Nafady et al, dalam Masri et al, 2017).

Pengalaman dan pelatihan dalam pemasangan drainage dada diperlukan untuk menghindari komplikasi yang bahkan bisa mematikan (Bertoglio et al, 2019). Menurut Kesieme et al (2012) komplikasi pemasangan drainage dada kadang dapat mengancam jiwa. Komplikasi ini secara luas diklasifikasikan sebagai teknis atau infektif. Penyebab teknis termasuk tube malposition (TM), drainase yang tersumbat, dislodgement drain, edema paru reekspansi, emfisema subkutan, cedera saraf, cedera jantung dan pembuluh darah, cedera esofagus, residu/postextubation pneumotoraks, fistula, kekambuhan tumor di lokasi pemasangan, herniasi melalui lokasi torakostomi, chylothorax dan disritmia jantung. Komplikasi infeksi termasuk empiema dan infeksi di tempat bedah. Penelitian John et al (2014) menyebutkan tingkat insiden TM dan komplikasi lebih tinggi pada pemasangan dengan teknik trocar. Ulasan CT scan dari 51 pasien yang dilakukan pemasangan teridentifikasi $29 \%$ dari pasien yang menjalani thoracostomy trocar memiliki TM, dibandingkan dengan $19 \%$ pada diseksi tumpul, empat pasien menderita hematoma intraparenchymallung. Lokasi pemasangan drainage dada juga memiliki tingkat TM 33\% vs 9\% untuk penempatan dorsal vs ventral ke garis mid-aksila.

Penelitian Rosadi dkk (2014) yang dilakukan di RS Persahabatan, Jakarta, dari 43 responden yang dilakukan pemasangan drainage dada, sebagian besar $(48,8 \%)$ dengan indikasi pneumotoraks. Rata-rata pemasangan drainage dada sampai dilepaskan adalah 17,3 $\pm 11,3$ hari. Mortalitas akibat pemasangan drainage dada 2,3\% (1/43) dan akibat penyakit dasarnya 16,3\% (7/43) dengan penyebab terbanyak adalah gagal napas (50\%). Menurut penelitian Kesieme (2012), hanya 37 responden $(26,2 \%)$ yang memiliki pengetahuan yang baik tentang perawatan drainage dada. Responden yang menjawab tidak memuaskan pada pertanyaan tentang posisi sistem drainase saat mobilisasi pasien, penerapan suction dan penggantian botol dada setiap hari. Pengetahuan 
perawat tentang perawatan drainase dada adalah buruk, terutama dalam perawatan pasca prosedur pemasangan WSD. Ada kebutuhan terkait pelatihan sehingga dapat meningkatkan asuhan keperawatan pasien dengan drainage dada.

Berdasarkan data yang diperoleh dari medikal rekord RSUD Ulin Banjarmasin, jumlah pemasangan drainage dada pada tahun 2016 sebanyak 42 orang, tahun 2017 meningkat menjadi 49 orang, tahun 2018 menurun sebanyak 41 orang dan selama bulan Januari-Juli 2019 sebanyak 21 orang. Kasus kematian yang terjadi pada saat pasien terpasang drainage dada tahun 2016 sebanyak 2,3\% (1/42) dengan kasus MPE, tahun 2017 sebanyak 2,04\% (1/49) dengan kasus sepsis empiema recurent, tahun 2018 meningkat menjadi $4,87 \%$ (2/41) dengan kasus MPE dan pneumothorax, sedangkan sampai pertengahan tahun 2019 belum ada kasus kematian. Kasus infeksi luka pada pasien yang terpasang drainage dada pada tahun 2016 sebanyak (9,52\%), tahun 2017 meningkat sebanyak (16,32\%), tahun 2018 menurun sebanyak $(14,63 \%)$ dan hingga pertengahan tahun 2019 kasus infeksi masih tercatat $(10,71 \%)$. Ruang perawatan terbanyak pada pasien dengan drainage dada adalah Ruang Dahlia dan Ruang Tulip Bedah. Jumlah perawat yang tercatat di bagian kepegawaian sebanyak 670 orang yang terdiri perawat ners sebanyak $(29,55 \%)$ dan DIII keperawatan sebanyak $(70,45 \%)$.

Berdasarkan studi pendahuluan yang dilakukan peneliti pada bulan Agustus 2019 di RSUD Ulin Banjarmasin, pedoman standar operasional prosedur (SOP) perawatan water seal drainage (WSD) sudah dibuat dan diberlakukan sejak tahun 2015, namun untuk pelatihan perawatan water seal drainage (WSD) kepada perawat belum pernah dilaksanakan baik ke rumah sakit lain maupun in house training di lingkungan RSUD Ulin Banjarmasin.

Peneliti kemudian melakukan wawancara kepada tujuh orang perawat diruang rawat inap dan dijelaskan bahwa dalam pelaksanaan perawatan pasien dengan pemasangan drainage dada hanya melakukan penggantian kasa saja seperti merawat luka pada umumnya, namun kurang memahami tentang bagaimana mempertahankan kepatenan sistem drainage, melakukan penilaian tekanan negatif dan penilaian reekspansi paru baik secara pemeriksaan fisik maupun radiologis. Perhitungan kuantitatif produksi cairan pleura dan melakukan pergantian botol cairan pleura juga jarang dilakukan.

pengetahuan yang memadai mengenai posisi drain dada, mengendalikan evakuasi cairan, mengidentifikasi kapan harus mengganti atau mengosongkan botol, merawat drain dan sistem drainase selama transportasi pasien. Hasil penelitian Kesieme et al (2016) dimana hanya $33,3 \%$ responden mengikuti simposium tentang asuhan keperawatan drainase dada. Angka rendah dimana hanya $12 \%$ responden yang menerima pendidikan formal dan hanya $34 \%$ merasa yakin dalam mengelola drainase dada. Studi lain mengungkapkan bahwa hanya $11,9 \%$ yang menghadiri lokakarya manajemen drainase dada.

Perawat yang melakukan perawatan WSD tentunya akan menemui berbagai masalah dan 
komplikasi dapat timbul selama perawatan seperti infeksi, selang tersumbat, nekrotik jaringan dan masih banyak lagi komplikasi lainnya. Perawatan yang baik tentunya berdasarkan atas kepatuhan yang baik sehingga perlu dilakukan upaya perubahan didalam proses tersebut. Rogers mengenalkan teori berubah meliputi konsep difusi. Difusi perubahan merupakan suatu proses akan kebutuhan perubahan (inovasi) yang dikomunikasikan pada manusia atau sistem. Teori perubahan Rogers diharapkan dapat memberikan sesuatu hal yang penting untuk mencapai kemajuan, sehingga perawat menjadi seorang yang berkomitmen, berpengaruh, berperilaku efektif, dan mampu memberikan pelayanan perawatan yang safety dan sesuai dengan standar dalam pelaksanaan implementasi keperawatan pada pasien dengan pemasangan WSD di rumah sakit.

Beberapa staf perawat di ruang perawatan RSUD Ulin Banjarmasin mungkin kurang memiliki kepatuhan dalam pelaksanaan perawatan drainase dada karena keragaman pendidikan, pelatihan dan masa kerja yang berbeda. Pendidikan dan pelatihan yang tepat untuk staf perawat sangat penting, oleh karena itu peneliti merasa perlu untuk meningkatkan kepatuhan staf perawat dalam pelaksanan perawatan WSD sesuai SPO yang ada di RSUD Ulin Banjarmasin.

\section{METODOLOGI PENELITIAN}

Penelitian ini menggunakan desain quasi experiment dengan pendekatan one group pre-post test without control group design (Pollit \& Beck, 2004). Penelitian ini mengukur kepatuhan pada kelompok yang diberikan pelatihan perawatan WSD sesuai SPO sebelum dan sesudah dilakukan pelatihan. Desain penelitian dengan pendekatan one group pre-post test without control group design

Populasi pada penelitian ini adalah semua perawat klinik (PK) II dengan masa kerja $\geq 3$ tahun yang bekerja di ruang rawat inap RSUD Ulin Banjarmasin. Jumlah PK II yang tercatat di bagian kepegawaian sampai tahun 2019 berjumlah 260 orang.

Pada penelitian ini peneliti mengambil sampel PK II berjumlah 20 responden dengan kriteria inklusi yaitu:

1. PK II (Advance Beginner) memiliki latar belakang pendidikan DIII Keperawatan dengan pengalaman kerja $\geq 3$ tahun dan menjalani masa klinis level II selama 6 - 9 tahun.

2. PK II (Advance Beginner) memiliki latar belakang pendidikan Ners dengan pengalaman kerja $\geq 3$ tahun dan menjalani masa klinis level II selama 4-7 tahun.

3. Bersedia menjadi responden penelitian

\section{HASIL}

Hasil rekapitulasi observasi pada penelitian dilakukan dengan menggunakan uji frekuensi dan uji deskriptif tentang pengaruh pelatihan terhadap kepatuhan perawat dalam pelaksanaan perawatan WSD sesuai SPO di RSUD Ulin Banjarmasin dapat dilihat pada tabel berikut : 
Jurnal Keperawatan Suaka Insan | Volume 5 Edisi I, Juni 2020

Tabel 1. Distribusi Frekuensi Karakteristik

Responden

\begin{tabular}{ccc}
\hline Variabel & Frekuensi & Persentase \\
\hline Usia & 4 & $20 \%$ \\
$20-25$ tahun & 6 & $30 \%$ \\
$31-30$ tahun & 4 & $20 \%$ \\
$\geq 35$ tahun & 6 & $30 \%$ \\
\hline Status Perkawinan & & \\
Belum kawin & 5 & $25 \%$ \\
Sudah kawin & 15 & $75 \%$ \\
\hline Jenis kelamin & & \\
Laki-laki & 5 & $25 \%$ \\
Perempuan & 15 & $75 \%$ \\
\hline Tingkat pendidikan & & \\
D III Keperawatan & 16 & $80 \%$ \\
Ners & 4 & $20 \%$ \\
\hline Masa Kerja & & \\
$\geq 3$ tahun & 4 & $20 \%$ \\
$3-5$ tahun & 6 & $30 \%$ \\
$5-7$ tahun & 0 & $0 \%$ \\
$\geq 7$ tahun & 10 & $50 \%$
\end{tabular}

Tabel 1 menunjukkan bahwa sebagian besar responden berusia 26 - 30 tahun 6 orang atau $30 \%$ dan $\geq 35$ tahun berjumlah 6 orang atau $30 \%$. Status perkawinan responden terbanyak adalah sudah kawin berjumlah 15 orang atau $75 \%$, jenis kelamin responden terbanyak adalah perempuan yaitu berjumlah 15 orang atau $75 \%$, dan tingkat pendidikan adalah D III Keperawatan berjumlah 16 orang atau $80 \%$ serta masa kerja responden terbanyak adalah $\geq 7$ tahun berjumlah 10 orang atau $50 \%$.
Tabel 2. Distribusi frekuensi Pre dan Post Test

Kepatuhan Perawat Dalam Pelaksanaan Perawatan WSD sesuai SPO

\section{Pre Test}

$\begin{array}{cccccl}\text { N } & \text { Nilai } & \text { Nilai } & \text { Standar } & \text { Nilai } & \text { Nilai } \\ & \text { range } & \text { Mean } & \text { Deviasi } & \text { Minimum } & \text { Maksimum }\end{array}$

$\begin{array}{llllll}20 & 4 & 32.00 & 1.451 & 30 & 34\end{array}$

\begin{tabular}{llllll}
\multicolumn{2}{l}{ Post Test } & & & \\
N & Nilai & Nilai & Standar & Nilai & Nilai \\
& range & Mean & Deviasi & Minimum & Maksimum
\end{tabular}

$\begin{array}{lllll}20 & 2 & 39.40 & 0.821 & 38\end{array}$

40

test kepatuhan perawat dalam pelaksanaan perawatan WSD sesuai SPO di RSUD Ulin Banjarmasin yaitu 32,00 (94,12\%), perawat melakukan 34 dari total 45 item nilai maksimal hasil observasi tentang alat ukur pre test kepatuhan perawat dalam pelaksanaan perawatan WSD sesuai SPO di RSUD Ulin Banjarmasin.

Tabel 2 juga menjelaskan nilai rerata variabel post test kepatuhan perawat dalam pelaksanaan perawatan WSD sesuai SPO di RSUD Ulin Banjarmasin yaitu $39,40 \quad(98,5 \%)$, perawat melakukan 40 dari total 45 nilai maksimal observasi tentang alat ukur post test kepatuhan perawat dalam pelaksanaan perawatan WSD sesuai SPO di RSUD Ulin Banjarmasin.

\section{Uji Normalitas}

Uji ini untuk mengetahui populasi data berdistribusi normal atau tidak sebagai persyaratan menggunakan metode parametrik. Uji yang 
digunakan yaitu dengan mendeteksi atau melihat persebaran data (titik) pada sumbu diagonal grafik P Plot dari residualnya dengan ketentuan:

1. Data dikatakan berdistribusi normal, jika data menyebar disekitar garis diagonal dan mengikuti arah garis diagonal atau grafik P Plot.

2. Sebaliknya data dikatakan tidak berdistribusi normal, jika data menyebar jauh dari arah garis atau tidak mengikuti diagonal atau grafik P Plot

\section{Gambar 1. Normal P Plot pre test kepatuhan perawat dalam pelaksanaan perawatan WSD sesuai SPO}

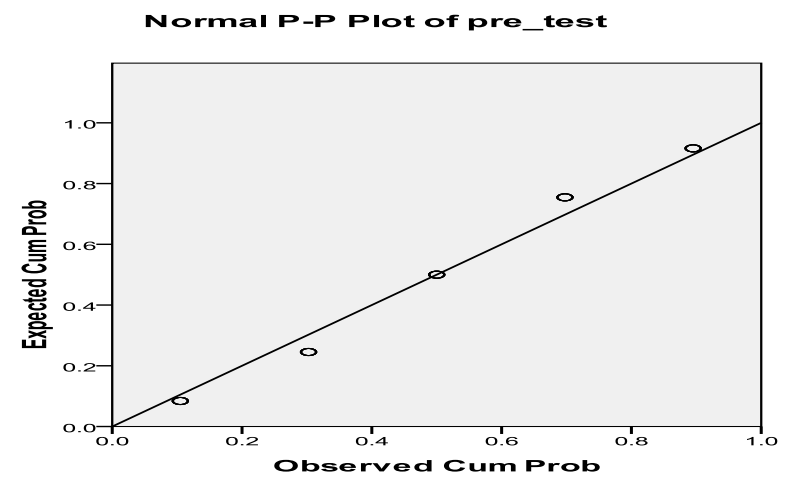

Gambar 2. Normal P Plot post test kepatuhan perawat dalam pelaksanaan perawatan WSD sesuai SPO

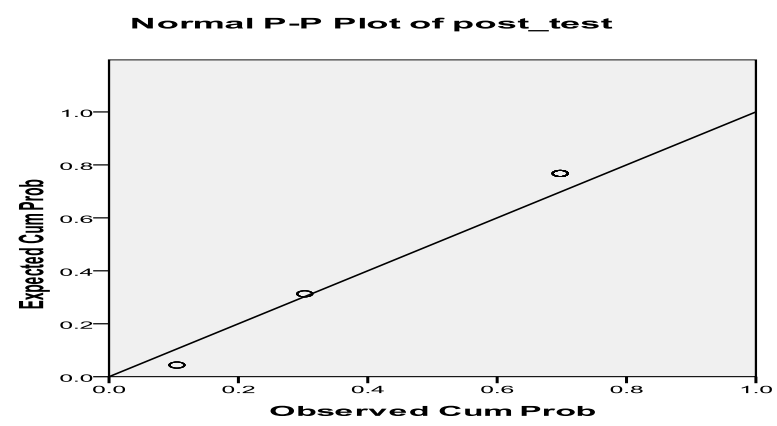

Hasil pada gambar 1 dan 2 menjelaskan bahwa data pre test dan post test kepatuhan perawat dalam pelaksanaan perawatan WSD sesuai SPO di RSUD Ulin Banjarmasin menyebar

disekitar garis diagonal dan mengikuti arah garis diagonal atau grafik $\mathrm{P}$ Plot sehingga dapat disimpulkan bahwa data berdistribusi normal.

Tabel 3. Paired Samples Statistics

\begin{tabular}{|c|c|c|c|c|c|}
\hline & & Mean & $\mathrm{N}$ & $\begin{array}{c}\text { Std. } \\
\text { Deviation }\end{array}$ & $\begin{array}{c}\text { Std. Error } \\
\text { Mean }\end{array}$ \\
\hline pair & $\begin{array}{l}\text { Pre } \\
\text { test }\end{array}$ & 32,00 & 20 & 1,451 & 0,324 \\
\hline 1 & $\begin{array}{l}\text { Post } \\
\text { test }\end{array}$ & 39,40 & 20 & 0,821 & 0,184 \\
\hline
\end{tabular}

Tabel 3 menunjukkan hasil uji Paired Samples Statistics yang erlihat bahwa mean pre tes kepatuhan perawat dalam pelaksanaan perawatan WSD sesuai SPO di RSUD Ulin Banjarmasin sebesar 32,00 dan post test kepatuhan perawat dalam pelaksanaan perawatan WSD sesuai SPO di RSUD Ulin Banjarmasin sebesar 39,40. Untuk standar deviasi pre test kepatuhan perawat dalam pelaksanaan perawatan WSD sesuai SPO di RSUD Ulin Banjarmasin sebesar 1,451 dan post test kepatuhan perawat dalam perawatan WSD sesuai SPO di RSUD Ulin Banjarmasin sebesar 0,821, serta nilai standar error mean pre test kepatuhan perawat dalam pelaksanaan perawatan WSD sesuai SPO di RSUD Ulin Banjarmasin sebesar 0,324 dan post test kepatuhan perawat dalam pelaksanaan perawatan WSD sesuai SPO di RSUD Ulin Banjarmasin sebesar 0,184. 
Tabel 4. Paired Samples Test

\begin{tabular}{|c|c|c|c|c|c|c|c|c|}
\hline & \multicolumn{5}{|c|}{ Paired Differences } & \multirow{3}{*}{$\mathrm{T}$} & \multirow{3}{*}{$\mathrm{df}$} & \multirow{3}{*}{$\begin{array}{l}\text { Sig. } \\
(2- \\
\text { tailed })\end{array}$} \\
\hline & \multirow[t]{2}{*}{ Mean } & \multirow[t]{2}{*}{$\begin{array}{l}\text { Std. } \\
\text { Devi } \\
\text { ation }\end{array}$} & \multirow[t]{2}{*}{$\begin{array}{l}\text { Std. } \\
\text { Error } \\
\text { Mean }\end{array}$} & \multicolumn{2}{|c|}{$\begin{array}{l}\text { 95\% Confidence } \\
\text { Interval of the } \\
\text { Difference }\end{array}$} & & & \\
\hline & & & & Lower & Upper & & & \\
\hline $\begin{array}{c}\text { pair } 1 \\
\text { Pre } \\
\text { tes \& } \\
\text { post } \\
\text { test }\end{array}$ & $\begin{array}{c}- \\
7,400\end{array}$ & 1,392 & 0,311 & $-8,051$ & $\begin{array}{c}- \\
6,749\end{array}$ & $\begin{array}{c}23 \\
77 \\
9\end{array}$ & $\begin{array}{l}1 \\
9\end{array}$ & 0,000 \\
\hline
\end{tabular}

Hasil uji Paired Samples Test pada Tabel 4 dapat dilihat bahwa signifikansi hitung adalah $0,000<0,05$, Ho ditolak dan Ha diterima, sehingga dapat disimpulkan bahwa terdapat pengaruh pelatihan terhadap kepatuhan perawat dalam pelaksanaan perawatan WSD sesuai SPO di RSUD Ulin Banjarmasin.

Tabel 4 juga memperlihatkan uji Paired Samples Test yang dapat dilihat bahwa berdasarkan hasil hitung Mean Paired Differences yaitu sebesar-7,400. Nilai dapat menunjukkan bahwa adanya nilai mean selisih antara pre test kepatuhan perawat dalam pelaksanaan perawatan WSD sesuai SPO sebesar 32,00 dengan post test kepatuhan perawat dalam pelaksanaan perawatan WSD sesuai SPO di RSUD Ulin Banjarmasin sebesar 39,40. Hasil dari uji 95\% Confidence Interval of the Difference yaitu hasil hitung Mean Paired Differences yaitu sebesar - 7,400 berada diantara nilai lower sebesar -8,051 sampai dengan nilai upper sebesar $-6,749$, hal ini dapat disimpulkan bahwa terdapat perubahan kepatuhan sebelum dan sesudah mendapatkan pelatihan pelaksanaan perawatan WSD sesuai SPO di RSUD Ulin Banjarmasin.

\section{PEMBAHASAN}

Sesuai dengan tujuan dari hipotesis penelitian ini, diperoleh hasil bahwa terdapat pengaruh pelatihan terhadap kepatuhan pelaksanaan perawatan WSD sesuai SPO di RSUD Ulin Banjarmasin, hal ini dapat dijelaskan sebagai berikut:

Karakteristik Perawat Yang Meliputi Usia, Status Perkawinan, Jenis Kelamin, Tingkat Pendidikan dan Masa Kerja.

Hasil uji deskriptif didapatkan bahwa sebagian besar responden berusia 26 - 30 tahun dan $\geq 35$ tahun, status perkawinan responden terbanyak adalah sudah kawin, jenis kelamin responden terbanyak adalah perempuan, tingkat pendidikan adalah D III Keperawatan dan masa kerja responden terbanyak adalah $\geq 7$ tahun. Hal ini dapat dijelaskan bahwa responden yang bekerja mempunyai karakteristik usia yang produktif sehingga dalam melakukan pekerjaan terutama dalam melaksanakan asuhan keperawatan pada pasien yang terpasang WSD dapat dilakukan. Usia berkaitan dengan kematangan, kedewasaan, dan kemampuan seseorang dalam bekerja. Semakin bertambah usia semakin mampu menunjukkan kematangan jiwa dan semakin cepat berfikir rasional, mampu untuk menentukan keputusan, semakin bijaksana, mampu mengontrol emosi, taat terhadap aturan dan norma dan komitmen terhadap pekerjaan. Seseoarang yang semakin bertambah usia, akan semakin terlihat berpengalaman, pengambilan keputusan dengan penuh pertimbangan, bijaksana, mampu mengendalikan 
emosi dan mempunyai etika kerja yang kuat dan komitmen terhadap mutu (Robbins, 2008).

Responden juga mempunyai proporsi terbanyak berstatus sudah kawin. Status perkawinan seseorang berpengaruh terhadap perilaku seseorang dalam bekerja. Karyawan yang menikah lebih sedikit absensinya, lebih puas dengan pekerjaannya dibandingkan dengan temannya yang belum menikah. Status perkawinan merupakan salah faktor seseorang yang mempengaruhi kenerja seseorang perawat. Perkawinan membuat seseorang menjadi mempunyai rasa tanggung jawab, kesiapan dalam pekerjaan menjadi lebih berharga dan penting (Robbins, 2008). Ada suatu yang berbeda dalam memaknai suatu pekerjaan. Seseorang perawat yang sudah menikah menilai pekerjaan sangat penting karena sudah memiliki sejumlah tanggung jawab sebagai keluarga dibandingkan dengan yang belum menikah (Sopiah, 2009).

Responden dengan proporsi terbanyak berjenis kelamin perempuan, hal ini dapat jelaskan bahwa profesi keperawatan yang bekerja di RSUD Ulin Banjarmasin lebih dominan perempuan sehingga didalam melaksanakan asuhan keperawatan dapat dilakukan dengan teliti dan profesional. Jenis kelamin laki-laki dan perempuan secara umum tidak menunjukkan perbedaan yang berarti dalam melaksanakan pekerjaan. Teori psikologi menjumpai bahwa wanita lebih bersedia untuk mematuhi wewenang dan pria lebih agresif dan lebih besar kemungkinannya dari pada wanita dalam memiliki pengharapan untuk sukses, meskipun perbedaan ini kecil (Robbins, 2008).
Proporsi tingkat pendidikan terbanyak responden yang melaksanakan perawatan WSD di RSUD Ulin Banjarmasin adalah D-III Keperawatan dan mempunyai masa kerja yang cukup, sehingga dalam melaksanakan asuhan keperawatan sesuai dengan dengan standar minimal tenaga perawat yang ditetapkan oleh RSUD Ulin Banjarmasin dan dilihat dari masa kerja responden bahwa perawat mempunyai pengalaman dalam menerapkan teori dan praktik sehingga penerapan pelaksanaan perawatan WSD dapat dilakukan. Tingkat pendidikan akan berpengaruh terhadap kemampuan seseorang dalam bekerja. Seseorang dengan tingkat pendidikan yang lebih tinggi diasumsikan memiliki pengetahuan dan keterampilan yang lebih baik dalam kemampuan menyelesaikan pekerjaan. Tingkat pendidikan perawat mempengaruhi kinerja perawat yang bersangkutan. Tenaga keperawatan yang berpendidikan tinggi kinerjanya akan lebih baik karena telah memiliki pengetahuan dan wawasan yang lebih luas, dapat memberikan saran atau masukan yang bermanfaat terhadap manajer keperawatan dalam meningkatkan kinerja keperawatan (Siagian, 1999).

Masa kerja berkaitan dengan lama seseorang bekerja menjalankan pekerjaan tertentu. Perawat yang bekerja lebih lama diharapkan lebih berpengalaman dan senior. Senioritas dan produktivitas pekerjaan berkaitan secara positif. Perawat yang bekerja lebih lama akan lebih berpengalaman dalam melakukan pekerjaannya dan semakin rendah keinginan perawat untuk meninggalkan pekerjaannya (Sopiah, 2009). 
Kepatuhan Perawat Sebelum Mendapatkan Pelatihan Perawatan WSD Sesuai SPO di RSUD Ulin Banjarmasin.

Hasil dari uji didapatkan bahwa rata-rata pre test responden mempunyai kepatuhan perawat dalam pelaksanaan perawatan WSD sesuai SPO di RSUD Ulin Banjarmasin. Hal ini dapat menjelaskan bahwa penerapan SPO masih dapat diterapkan oleh perawat dalam melaksanakan perawatan WSD di RSUD Ulin Banjarmasin.

Pelaksanaan perawatan dan asuhan keperawatan oleh perawat memang perlu diterapkan secara maksimal terutama di rawat inap. Menurut Sacket dalam Niven (2002) kepatuhan adalah sejauh mana perilaku perawat sesuai dengan ketentuan yang diberikan oleh profesional kesehatan. Perilaku yang disiplin merupakan perilaku yang taat dan patuh dalam peraturan. Kepatuhan merupakan suatu tahap awal perilaku, maka semua faktor yang mendukung atau mempengaruhi perilaku juga akan mempengaruhi kepatuhan (Unarajan, 2003).

Perubahan sikap dan perilaku dimulai dari kepatuhan, identifikasi, kemudian internalisasi. Menurut riset yang dilakukan oleh Laksono (2018) disimpulkan ada hubungan pendidikan, pengetahuan, lama kerja, pelatihan, dan motivasi dengan kepatuhan perawat terhadap pelaksanaan SPO rawat luka paska operasi di ruang rawat inap khusus bedah RSUD Kota Madiun, sedangkan menurut Gibson ada tiga kelompok variabel yang mempengaruhi perilaku kerja dan kinerja seseorang yaitu faktor individu, faktor organisasi dan faktor psikologi (Gibson, 2003).
Penelitian Kesieme et al (2016) menjelaskan bahwa hanya 33,3\% responden mengikuti simposium tentang asuhan keperawatan drainase dada. Angka rendah dimana hanya 12\% responden yang menerima pendidikan formal dan hanya $34 \%$ merasa yakin dalam mengelola drainase dada. Studi lain mengungkapkan bahwa hanya 11,9\% yang menghadiri lokakarya manajemen drainase dada.

Faktor seperti diatas juga menjadi kendala dalam pelaksanaan perawatan WSD oleh perawat di RSUD Ulin Banjarmasin dimana individuindividu tersebut kurang ingin meningkatkan kompetensi dan hanya menerapkan teori dan teknik yang lama, padahal dalam perawatan WSD setiap pelaksanaan selalu berkembang mengikuti perkembangan IPTEK. Hasil penelitian ini juga menemukan sebagian besar perawat dalam hal melakukan evaluasi ekspansi paru masih belum begitu maksimal, hal ini dikarenakan perawat jarang melakukan pemeriksaan fisik kepada pasien terkait palpasi, perkusi dan auskultasi pada sistem pernapasan serta kurangnya pemahaman tentang gambaran radiologis seperti penilaian foto thorax. Pemantauan kondisi pasien post pemasangan WSD dengan cermat sangat penting untuk mengetahui tanda dan gejala gangguan pernapasan dengan menggunakan oksimetri nadi $(\mathrm{SpO} 2)$ dan auskultasi suara napas. Pemantauan pengembangan ekspansi paru juga dapat dilakukan melalui penilaian foto thorax yang dilakukan dengan membandingkan foto-foto sebelumnya dan untuk mengevaluasi keberadaan atau kembalinya pneumotoraks, efusi pleura atau masalah lainnya. 
Pengetahuan dan keterampilan tentang manajemen drainage dada perlu ditingkatkan untuk meningkatkan kepercayaan diri dalam memberikan perawatan pasien yang aman.

Tidak terlepas dari permasalah dari perawat itu sendiri, ada faktor lain yang berkaitan dengan penerapan SPO perawatan WSD terutama mengenai peralatan medis dan sterilisasinya. Perawat menunjukkan defisit dalam pengetahuan dan praktik perawatan drainage dada. Memang ada beberapa kendala yang terjadi dalam penerapan pelaksanaan perawatan WSD terutama dalam pengadaan alat medis dan kelengkapan instrumen medis untuk perawatan WSD. Hal ini menjadi kendala yang dihadapi oleh perawat pelaksana dimana pengadaan alat instrumen perawatan WSD terkait dengan pihak manajemen. Tidak terlepas dari hal tersebut instrumen perawatan WSD juga terkait dengan Central Sterile Supply Department (CSSD). CSSD merupakan sentral untuk steril alatalat medis. Pada pelaksanaannya sterilisasi di CSSD dengan cara memisah alat-alat, sehingga instrumen alat perawatan WSD tidak lengkap saat dikembalikan ke rawap inap (Depkes RI, 2009).

CSSD sebaiknya memverifikasi alat-alat yang dibutuhkan dan kelengkapannya di rawat inap untuk melakukan perawatan WSD. Apabila hal ini dapat diterapkan oleh CSSD maka penerapan SPO perawatan WSD dapat dilaksanakan sesuai ketentuan yang berlaku di RSUD Ulin Banjarmasin.

Selain hal tersebut hasil penelitian ini juga menemukan sebagian besar perawat dalam hal melakukan pemantauan sistem drainage dada terutama yang menggunakan sistem drainage komersial atau elektronik juga masih belum begitu maksimal, hal ini dikarenakan perawat kurang memahami tentang bagaimana cara penggunaan alat tersebut.

Prolonged Air Leak (PAL) merupakan kebocoran udara yang berlangsung setelah hari ke5 pasca operasi. Faktor-faktor risiko yang paling konsisten dilaporkan untuk PAL termasuk fungsi paru yang buruk, penggunaan terapi steroid, adanya pneumotoraks yang bertepatan dengan kebocoran udara serta adanya adhesi pleura. Insiden PAL yang dilaporkan berkisar antara $8 \%$ hingga 26\%. PAL akan meningkatkan angka length of stay (LOS), meningkatkan biaya rumah sakit dan dikaitkan dengan peningkatan kejadian empiema serta komplikasi lainnya

Hasil penelitian di RSUD Ulin Banjarmasin dapat disimpulkan bahwa cukup baiknya penerapan pelaksanaan perawatan WSD sesuai SPO oleh perawat dengan optimalisasi dan koordinasi pihak terkait dalam memberikan asuhan keperawatan WSD.

Kepatuhan Perawat Sesudah Mendapatkan Pelatihan Perawatan WSD Sesuai SPO di RSUD Ulin Banjarmasin.

Hasil uji didapatkan bahwa rata-rata post test responden mempunyai kepatuhan perawat dalam pelaksanaan perawatan WSD sesuai SPO di RSUD Ulin Banjarmasin. Dapat dijelaskan bahwa dengan adanya pelatihan perawatan WSD maka penerapan pelaksanaan asuhan keperawatan sesuai SPO dapat dilakukan sesuai dengan yang 
diharapkan oleh pihak RSUD Ulin Banjarmasin. Penerapan SPO ini tidak terlepas dari peningkatan dan pengembangan pengetahuan dan keterampilan yang diberikan secara aktif yaitu memberikan pelatihan yang sesuai dengan standar sehingga pelaksanaan perawatan WSD dapat dilakukan oleh perawat. Pelatihan menurut Undang-undang Nomor 13 Tahun 2003 tentang Ketenagakerjaan pasal 1 ayat 9 mengungkapkan bahwa pelatihan kerja adalah keseluruhan kegiatan untuk memberi, memperoleh, meningkatkan, serta mengembangkan kompetensi kerja, produktivitas, disiplin, sikap, dan etos kerja pada tingkat keterampilan dan keahlian tertentu sesuai dengan jenjang dan kualifikasi jabatan dan pekerjaan. Gomes (2003) mengungkapkan bahwa pelatihan merupakan setiap usaha untuk memperbaiki performa pekerja pada suatu pekerjaan tertentu yang sedang menjadi tanggungjawabnya, atau satu pekerjaan yang ada kaitannya dengan pekerjaannya, sedangkan Rivai (2009) mengungkapkan bahwa pelatihan merupakan suatu kegiatan untuk meningkatkan kinerja saat ini dan di masa mendatang atau diungkapkan lebih lanjut yaitu pelatihan merupakan proses secara sistematis mengubah tingkah laku pegawai untuk mencapai tujuan organisasi. Pelatihan berkaitan dengan keahlian dan kemampuan pegawai untuk melaksanakan pekerjannya saat ini. Pelatihan memiliki orientasi dan membantu pegawai untuk mencapai keahlian dan kemampuan tertentu agar berhasil dalam melaksanakan pekerjaannya.

Simamora (2006) menjelaskan bahwa manfaat pelatihan adalah untuk meningkatkan kuantitas dan kualitas produktivitas, mengurangi waktu belajar yang diperlukan pegawai agar mencapai standar-standar kinerja yang dapat diterima, menciptakan sikap, loyalitas dan kerjasama yang lebih menguntungkan, memenuhi kebutuhan-kebutuhan dan kerjasama yang lebih menguntungkan, memenuhi kebutuhan-kebutuhan perencanaan sumber daya manusia, membantu pegawai dalam peningkatan dan pengembangan pribadi mereka.

Indikator pelatihan menurut Mangkunegara (2013) menjelaskan bahwa peserta pelatihan tentunya harus diseleksi berdasarkan persyaratan tertentu dan kualifikasi yang sesuai, selain itu peserta pelatihan juga harus memiliki semangat yang tinggi untuk mengikuti pelatihan. Pelatihan sumber daya manusia merupakan materi atau kurikulum yang sesuai dengan tujuan pelatihan yang hendak dicapai oleh organisasi dan materi pelatihan pun harus update agar peserta dapat memahami masalah yang terjadi pada kondisi sekarang. Metode pelatihan akan lebih menjamin berlangsungnya kegiatan pelatihan sumber daya manusia yang efektif apabila sesuai dengan jenis materi dan komponen peserta pelatihan.

Penerapan standar pelaksanaan perawatan WSD juga tidak terlepas dari koordinasi pihak manajemen dan CCSD. Penerapan yang sesuai dengan pelatihan tidak berjalan seiring dengan CSSD dimana standar yang digunakan dalam pelatihan perawatan WSD diharuskan instrument alat harus lengkap dan satu tempat. Tetapi dalam penerapannya CSSD memilah dan memisah alatalat tersebut karena CSSD menggunakan standar 
tersendiri dalam menyediakan alat perawatan WSD yang steril sehingga peneliti melihat bahwa perawat menjadi tidak bisa menerapkan sesuai SPO yang ditetapkan ,pemasangan WSD mungkin berhubungan dengan komplikasi parah, oleh karena itu indikasi untuk melakukannya harus sangat tepat. Aspek yang paling penting dalam konteks ini adalah tujuan perawatan yang harus dicapai melalui prosedur tersebut.

Sangat penting bagi pihak terkait CSSD melakukan sinkronisasi dalam penerapan SPO perawatan WSD sehingga perawat yang bekerja di rawat inap bisa melakukan dan melaksanakan asuhan keperawatan secara maksimal dan profesional sesuai SPO yang ditetapkan oleh RSUD Ulin Banjarmasin.

Sejalan dengan penelitian Chege et al (2018), dimana studi menunjukkan adanya kesenjangan dalam pengetahuan dan kompetensi perawat dalam manajemen Undergoing Underwater Chest Drainage (UWCD). Praktik keperawatan dalam perawatan UWCD bervariasi dengan kepatuhan yang rendah terhadap pedoman standar. Penelitian ini merekomendasikan perlunya memberikan pengajaran klinis dan pendidikan berkelanjutan kepada perawat tentang manajemen UWCD untuk meningkatkan kompetensi dan meningkatkan keselamatan pasien di rumah sakit dan standarisasi perawatan.

Tiga jenis sistem drainase dada untuk efusi pleura yaitu sistem drainase tertutup, sistem drainase terbuka dan sistem drainase isap dimana informasi tentang manajemen chest tube memiliki pendekatan yang lebih baik terhadap pasien, meminimalkan biaya dan limbah material serta mempromosikan komunikasi yang efisien di antara staf multidisiplin.

Terkait dengan evaluasi ekspansi paru dan pemantauan sistem drainage dada, semua aspek dari kondisi pasien perlu dipantau dengan sangat cermat. Informasi yang diperoleh oleh staf perawat sangat penting dan menjadi dasar untuk keputusan terapeutik. Ketika terjadi perubahan atau komplikasi, dokter yang bertugas harus segera diberitahu dan didokumentasikan dengan tepat.

Sistem drainage elektronik bermanfaat dalam mengurangi durasi pemasangan drainase dada dan memberikan kepuasan lebih daripada sistem konvensional.

Penggunaan suction dengan sistem elektronik sangat tepat karena penilaian kebocoran udara menjadi lebih objektif dan konsisten. Studi menunjukkan bahwa sistem elektronik merupakan penilaian kebocoran udara yang andal. Belum ada penelitian yang mendukung $-20 \mathrm{cmH} 2 \mathrm{O}$ sebagai tingkat pengisapan yang optimal, namun setidaknya dalam 50 tahun terakhir telah digunakan dan direkomendasikan oleh para ahli sebagai pengaturan awal yang aman. Penghisapan akan mengurangi lamanya waktu pemasangan WSD dan lamanya rawat inap .

Hasil penelitian ini dapat disimpulkan bahwa cukup baiknya penerapan pelatihan perawatan WSD tidak hanya dilakukan pelatihan SPO perawatan WSD tetapi sinkronisasi antar unit perlu juga diselaraskan sehingga pelayanan asuhan keperawatan dapat dilaksanakan sesuai ketentuan RSUD Ulin Banjarmasin. 
Perubahan Kepatuhan Perawat Sebelum dan Sesudah Mendapatkan Pelatihan Perawatan Water Seal Drainage Sesuai Standar Prosedur Operasional di RSUD Ulin Banjarmasin.

Hasil penelitian didapatkan bahwa terdapat perubahan kepatuhan perawat sebelum dan sesudah mendapatkan pelatihan perawatan WSD sesuai SPO di RSUD Ulin Banjarmasin. Hal ini dapat dijelaskan bahwa pelatihan merupakan faktor utama dalam meningkatkan kompetensi penerapan asuhan keperawatan terutama perawatan WSD. Pelatihan perawatan WSD ini tidak hanya memberikan pengetahuan baru dalam asuhan keperawatan tetapi menyelaraskan antara teori dan pelaksanaan perawat WSD dengan standar operasional prosedur perawatan WSD di rawat inap RSUD Ulin Banjarmasin.

Simamora (2006) menjelaskan bahwa pelatihan keahlian (skill training) merupakan pelatihan yang sering di jumpai dalam organisasi. Program pelatihaannya relatif sederhana yaitu kebutuhan atau kekurangan diidentifikasi rnelalui penilaian yang jeli, kriteria penilalan efekifitas pelatihan juga berdasarkan pada sasaran yang diidentifikasi dalam tahap penilaian.

Simamora yang dikutip oleh Sinambela (2012) dalam buku Kinerja Pegawai Teori, Pengukuran dan Implikasi mengungkapkan pengertian pelatihan merupakan serangkaian aktivitas yang dirancang untuk meningkatkan keahlian-keahlian, pengetahuan, pengalaman, ataupun perubahan sikap seseorang.

Pelatihan yang diberikan oleh pimpinan atau manajer terhadap bawahan perlu dilaksanakan agar bawahan termotivasi dalam menyelesaikan tugas yang menjadi tanggungjawab dan wewenangnya sehingga apa yang menjadi tujuan dalam organisasi tersebut dapat tercapai atau terlaksana dengan baik.

Pelatihan lebih terarah pada peningkatan kemampuan dan keahlian sumber daya manusia organisasi yang berkaitan dengan jabatan atau fungsi yang menjadi tanggungjawab individu yang bersangkutan saat ini (current job oriented). Sasaran yang ingin dicapai dan suatu program pelatihan adalah peningkatan kinerja individu dalam jabatan atau fungsi saat ini. Pelatihan yang dilaksanakan bertujuan untuk meningkatkan kemampuan atau kompetensi pegawai dalam mencapai tujuan yang ada.

Keterkaitan dalam peningkatan kompetensi perawatan WSD memang harus dilakukan oleh pihak rumah sakit, terutama yang bersifat teknis yaitu perawatan WSD sehingga standar yang sudah diterapkan bisa dioptimalkan dan perlu dikaji ulang setiap ada perubahan metode perawatan WSD yang baru. Penerapan SPO memang diharuskan oleh seluruh perawat terutama yang berkaitan dengan perawatan WSD agar pelaksanaan asuhan keperawatan mempunyai mutu yang baik secara kuantitas dan kualitas sehingga terlihat profesionalitas perawat dalam memberikan asuhan keperawatan di RSUD Ulin Banjarmasin. Hal inilah yang perlu ditingkatkan dengan pelatihan sesuai pendapat Lestari (2016) yang menyatakan bahwa pelatihan berpengaruh positif terhadap kinerja karyawan.

Pelatihan merupakan salah satu usaha untuk mengembangkan sumber daya manusia. 
Sebagaimana yang sudah dijelaskan pada item pelatihan memiliki tujuan salah satunya peningkatan produktifitas kerja dengan pengembangan, kualitas dan kuantitas produksi semakin baik, karena technical skill, human skill dan managerial skill pegawai semakin baik (Hasibuan, 2010). Upaya pelatihan yang dilakukan memberikan manfaat memenuhi kebutuhankebutuhan perencanaan sumber daya manusia serta menciptakan sikap, loyalitas dan secara otomatis dapat meningkatkan kepatuhan (Simamora, 2006).

Kepatuhan merupakan suatu tahap awal perilaku, maka semua faktor yang mendukung atau mempengaruhi perilaku juga akan mempengaruhi kepatuhan (Unarajan 2003). Hal ini menjadi bagian penting yang harus diperhatikan oleh perawat sebagai bentuk upaya untuk memaksimalkan layanan yang kompeten. Apabila pelatihan perawatan WSD sesuai SPO diterapkan secara berkala oleh pihak RSUD Ulin Banjarmasin, maka dapat meningkatkan profesionalisme perawat dan optimalnya pelayanan keperawatan dirumah sakit.

Hasil penelitian yang dilaksanakan di RSUD Ulin Banjarmasin dapat disimpulkan bahwa perawat dalam melakukan perawatan WSD yang bermutu harus mengacu kepada standar prosedur operasional yang ditetapkan oleh RSUD Ulin dan mengoptimalkan diri dengan meningkatkan pengetahuan dan keterampilan keperawatan.

\section{KESIMPULAN}

Berdasarkan pada hasil penelitian serta pembahasan, maka dapat diperoleh karakteristik perawat yaitu sebagian besar responden berusia 26
- 30 tahun 6 orang atau $30 \%$ dan $\geq 35$ tahun berjumlah 6 orang atau $30 \%$, status perkawinan responden terbanyak adalah sudah kawin berjumlah 15 orang atau $75 \%$, jenis kelamin responden terbanyak adalah perempuan yaitu berjumlah 15 orang atau $75 \%$, tingkat pendidikan adalah D III Keperawatan berjumlah 16 orang atau $80 \%$ dan masa kerja responden terbanyak adalah $\geq$ 7 tahun berjumlah 10 orang atau $50 \%$. Kepatuhan perawat sebelum mendapatkan pelatihan perawatan WSD sesuai SPO mean 32,00 dan sesudah mendapatkan pelatihan perawatan WSD sesuai SPO mean 39,40. Perubahan kepatuhan perawat sebelum dan sesudah mendapatkan pelatihan perawatan WSD Sesuai SPO hasil hitung Mean Paired Differences yaitu sebesar - 7,400 dengan signifikansi 0,000 .

Pihak manajemen SDM dan bidang DIKLIT agar selalu meningkatkan kemampuan perawat dengan cara menyelenggarakan pendidikan dan pelatihan, seminar dan workshop, baik formal maupun informal secara adil dan merata kepada perawat klinik II untuk meningkatkan pengetahuan dan keterampilan perawat menuju perawat profesional.

\section{DAFTAR PUSTAKA}

Ayoub, F., Quirke, M., \& Frith, D. (2019). Use of Prophylactic Antibiotic in Preventing Complications for Blunt and Penetrating Chest Trauma Requiring Chest Drain Insertion: A Systematic Review and MetaAnalysis. (1), 1-7. https://doi.org/10.1136/tsaco-2018-000246 
Bertoglio, P., Guerrera, F., Viti, A., Terzi, A. C., Ruffini, E., \& Filosso, P. L. (2019). Chest Drain and Thoracotomy for Chest Trauma. 11(Suppl 2), 186-191. https://doi.org/10.21037/jtd.2019.01.53

Chege, A., Mwaura, J., \& Kirui, A. (2018). Evaluation of the Nursing Management for Patients on Underwater Chest Drainage at Kenyatta National Hospital. 1222-1235. https://doi.org/10.4236/ojog.2018.812124

Depkes RI. (2009). Pedoman Instalasi Pusat Sterilisasi (Central Sterile Supply Departement/CSSD) di Rumah Sakit. Jakarta. Depkes RI

Gibson, J.L. Ivancevich, J.M, \& Donnelly, J.H. Organisasi: Perilaku, Struktur, Proses, Jilid 1, Jakarta: Binarupa Aksara Publisher. 2003.

Gomes, F.C. (2003). Manajemen Sumber Daya Manusia. Yogyakarta: Andi Offset.

Hasibuan, S.P. (2007). Manajemen Sumber Daya Manusia. Edisi revisi. Jakarta: Bumi Aksara.

John, M., Razi, S., Sainathan, S., \& Stavropoulos, C. (2014). Is The Trocar Technique for Tube Thoracostomy Safe in The Current Era? 19(March), $125-128$. https://doi.org/10.1093/icvts/ivu071

Kesieme, E. B., Essu. I.S., Georgi. (2016). Nurses' Knowledge of Care of Chest Drain: A Survey in A Nigerian Semiurban University Hospital. Annals of African Medicine, 15(2), 95. https://doi.org/10.4103/1596-3519.179737

Laksono, A (2018) Faktor-Faktor yang Berhubungan dengan Kepatuhan Petugas Keperawatan Terhadap Pelaksanaan Standar Prosedur Operasional Rawat Luka Paska Operasi (Post Op) di Ruang Rawat Inap Khusus Bedah RSUD Kota Madiun

Mangkunegara, A.A Anwar Prabu. (2013). Manajemen Sumber Daya Manusia Perusahaan. Bandung: PT. Remaja Rosda Karya.
Mohammed, M. A., Mahmoud, M. E., Sleem, H. A., \& Ibrahim, N. M. (2016). Assessment the Nurses Performance in Providing Care to Patients Undergoing Chest Tube in Suez Canal University Hospital.

Nafady, M., El, A., Ghanem, H. M., \& Khayat, H. El. (2017). Risk Factors That Increase Nosocomial Infections Among Patients with Chest Tube Risk Factors That Increase Nosocomial Infections Among Patients with Chest Tube. (July).

Nevin, Neil. (2002). Psikologi Kesehatan dan Pengantar untuk Perawat dan Professional Kesehatan Lain. Jakarta: EGC.

Peter, R. (2010). Learning Zone Nursing Care and Management of Patients with Intrapleural Drains.

Polit \& Beck. (2004). Nursing Research : Principles and Methods. $7^{\text {th }}$ Edition. Lippincoth Williams \& Wilkins.

Rivai \& Sagala. 2009. Manajemen Sumber Daya Manusia Edisi Kedua. Jakarta: Raja Grafindo Persada

Robbins, S.P \& Judge, TA. (2008). Perilaku Organisasi, Edisi 12. Jakarta: Salemba Empat.

Rosadi, A., Swidarmoko, B., \& Astowo, P. (2007). Komplikasi Pemasangan Kateter Toraks pada Berbagai Penyakit Pleura in Various Pleural Disease. 34(1), 26-35.

Sahib, S. M., Muktsar, S., \& Muktsar, S. (2019). A Study To Assess The Efficacy Of Self Instructional Module ( SIM ) On The Knowledge Regarding Nursing Management Of Patients With Chest Drainage Among Staff Nurses Of Selected Hospitals Of Malwa Region Of Punjab. 8(2), 11-17. https://doi.org/10.9790/1959-0802101117

Siagian, S.P. (1999). Manajemen Sumber Daya Manusia. Jakarta: Bumi Aksara.

Simamora. (2012). Kinerja Pegawai Teori 
Jurnal Keperawatan Suaka Insan | Volume 5 Edisi I, Juni 2020

Pengukuran dan Implikasi. Yogyakarta: Graha Ilmu.

Sopiah.(2009). Perilaku Organisasional.

Yogyakarta: Andi Yogyakarta.

Unarajan D. (2003). Manajemen Disiplin. Jakarta:

PT Grasindo. 